\title{
NOTES
}

\section{FIRST RECORD OF THE PURPLE MARTIN BREEDING IN IDAHO}

AUSTIN R. YOUNG, 2489 East 3758 North, Twin Falls, Idaho 83301;

austinyoung234@gmail.com

LIAM M. WATERS, 22 High Street, Sharon, Massachusetts 02067

The Purple Martin (Progne subis), the largest swallow (Hirundinidae) that is widespread in North America north of Mexico, breeds commonly over much of the eastern U.S. and central Canada (Brown and Tarof 2013). Sparser and often isolated breeding populations are scattered through the Pacific states (Kostka and McAllister 2005, Airola and Williams 2008) and southern British Columbia (Cousens et al. 2005), as well as the interior West from north-central Utah and western Colorado south to northern Mexico (Behle 1968, Doughty and Fergus 2002). The location of reported breeding nearest to Idaho is about $35 \mathrm{~km}$ to the south in northern Utah, where Purple Martins nest mainly in abandoned woodpecker holes in mature aspen or mixed forests near water at high elevations (Hayward 1941, 1958, Brown and Tarof 2013).

Here, we report the first documented instance of the Purple Martin breeding successfully in the state of Idaho. On 30 June 2019, Evan Lipton and Waters noted a one-year-old female (Figure 1; Pyle 1997) and a definitive-plumaged male (Figure 2) Purple Martin foraging around Lake Cleveland at $2530 \mathrm{~m}$ elevation in the Albion Mountains of central Cassia County, south-central Idaho $\left(42^{\circ} 19^{\prime} \mathrm{N}, 113^{\circ} 39^{\prime} \mathrm{W}\right)$. The next day, 1 July, Kathy Eklund observed martins entering a woodpecker cavity $20 \mathrm{~m}$ above the ground in a dead lodgepole pine (Pinus contorta). The nest tree was in a cluster of lodgepole pine snags on a small peninsula jutting into the lake. Lake Cleveland is surrounded by subalpine fir (Abies lasiocarpa), lodgepole pine, and exposed rock. The tree also contained a nest of the Tree Swallow (Tachycineta bicolor) with a nestling. On 2 August, birders observed both the male and female martin carrying food into the nest cavity, and on 3 August heard the nestlings' vocalizations. Similar observations, including the adults removing fecal sacs, continued through 6 August, until two nestlings were observed peering from the nest cavity on 7 August. Fledglings were first observed outside the nest cavity on 10 August, when two were seen being fed on adjacent branches (Figure 1). Observations of adults feeding fledglings continued through the last observation on the afternoon of 14 August. Searches on 16 August proved unsuccessful. It is worth noting the ages of the birds because colonizing Purple Martins are typically one year old (D. Airola pers. comm.); the female was that age, but the male was older.

The Purple Martin is considered casual in Idaho with only four records accepted by the Idaho Bird Records Committee (IBRC; Table 1, Figure 3). The additional 10 reports listed in Table 1 that have not been accepted by the IBRC were not rejected but have simply not been reviewed by the committee. Nonetheless, the unreviewed reports are valuable because they indicate potential locations where Purple Martins have occurred in the past and may occur again in the future. Most reports, including those not endorsed by IBRC, have been of birds in female-like plumage (which may have included yearling males, whose plumage may be superficially similar) from late April through June. In contrast, there are also four reported sightings of more than one individual between July and September (see Table 1), a pattern that suggests possible breeding or post-breeding dispersal from locations to the south. Two reports prior to ours suggest possible nesting of the Purple Martin in Idaho. 


\section{NOTES}

TABLE 1 Reports of the Purple Martin in Idaho

\begin{tabular}{|c|c|c|c|}
\hline Date & Notes & Locality & Citation $^{a}$ \\
\hline $20 \mathrm{Jul} 1948$ & Three individuals & $\begin{array}{l}4 \text { mi. sw of Lolo Pass, } \\
\text { Idaho Co. }\end{array}$ & Orr 1951 \\
\hline 28-29 May 1964 & Three individuals & $\begin{array}{l}\text { Minidoka National Wildlife } \\
\text { Refuge, Cassia Co. }\end{array}$ & Wilbur 1976 \\
\hline 1 Jun 1973 & Three individuals & Glenns Ferry, Elmore Co. & АВ 27:900, 1973 \\
\hline 13-14 Jul 1974 & $\begin{array}{l}\text { One male observed at cavity; } \\
\text { one female observed } 14 \text { July }\end{array}$ & $\begin{array}{l}\text { Micah Bay, Coeur } \\
\text { d'Alene, Kootenai Co. }\end{array}$ & IBRC report 2-B-76 \\
\hline 25 Jun 1977 & One individual & Twin Falls, Twin Falls Co. & АВ 31:1165, 1977 \\
\hline 6 Sep 1979 & Six foraging individuals & $\begin{array}{l}\text { Swan Falls, on Snake } \\
\text { River, Ada Co. }\end{array}$ & $\begin{array}{l}\text { Field notes of John } \\
\text { Dean }\end{array}$ \\
\hline 27 Jun 1982 & Unconfirmed pair & Stanley, Custer Co. & Field notes John Dean \\
\hline $\begin{array}{l}21 \text { Apr } 1984- \\
12 \text { May } 1984\end{array}$ & $\begin{array}{l}\text { One individual observed in } \\
\text { two counties }\end{array}$ & $\begin{array}{l}\text { Mountain Home, Elmore } \\
\text { Co., and Boise, Ada Co. }\end{array}$ & АВ 38:938, 1984 \\
\hline 21 Jun 1989 & One female ${ }^{b}$ & $\begin{array}{l}\text { Heise Hot Springs, } \\
\text { Bonneville Co. }\end{array}$ & IBRC report 2-A-89 \\
\hline 12 May 1995 & One female & $\begin{array}{l}\text { Deer Flat National Wildlife } \\
\text { Refuge, Ada Co. }\end{array}$ & NASFN 49:279, 1995 \\
\hline 11 Sep 2002 & One individual & Boise, Ada Co. & NAB 57(1):88, 2002 \\
\hline 24 Apr 2004 & One individual & Elmore Co. & NAB 58(3):403, 2004 \\
\hline 29-30 Jun 2007 & One female ${ }^{b}$ & $\begin{array}{l}\text { Heise Hot Springs, } \\
\text { Bonneville Co. }\end{array}$ & IBRC report 74-B-07 \\
\hline $31 \mathrm{Jul} 2019$ & $\begin{array}{l}\text { One male, one female, } \\
\text { two juveniles }\end{array}$ & Lake Cleveland, Cassia Co. & IBRC report 22-B-2019 \\
\hline
\end{tabular}

${ }^{a} \mathrm{AB}$, American Birds; IBRC, Idaho Bird Records Committee; NASFN, National Audubon Society Field Notes; NAB, North American Birds.

${ }^{b}$ Record endorsed by the Idaho Bird Records Committee.

These include one near Coeur d'Alene in northern Idaho on 13 July 1974, where a male was observed visiting a nest cavity and a female joined him the following day. Through the summer, however, only the male was observed (Table 1). The only other instance of possible breeding is an unconfirmed report of a pair observed in central Idaho on 27 June 1982 (Table 1). Unfortunately, no detailed notes or subsequent observations were recorded.

Purple Martins express high fidelity to a breeding site, seasonal social monogamy, and moderately high natal philopatry (Stutchbury et al. 2009, Brown and Tarof 2013). In light of these characteristics, it is possible that the pair and/or offspring may return to Lake Cleveland in future years, especially as western martins using tree cavities tend to nest in a solitary fashion with only one to two pairs per site (Stutchbury 1991, Brown and Tarof 2013). Other western martins, particularly in urban areas, tend to nest colonially, and sites supporting single pairs tend to be abandoned at a rate higher than do sites of colonies (Airola and Kopp 2018). Observations, or the lack thereof, during the following nesting season at this site and other areas of apparent suitable habitat may be valuable to understanding the Purple Martin as a species and follow up on an already notable nesting record.

We thank local birders for submitting their observations to www.eBird.org and local birding listservs, and to the Idaho Bird Records Committee for public access to its database (www.idahobirds.net/distribution/maps/martins-and-swallows/ purple-martin). Bryce W. Robinson, Daniel D. Gibson, and Chris W. Swarth were helpful in the process of creating and preparing this article. Daniel Airola provided 


\section{NOTES}

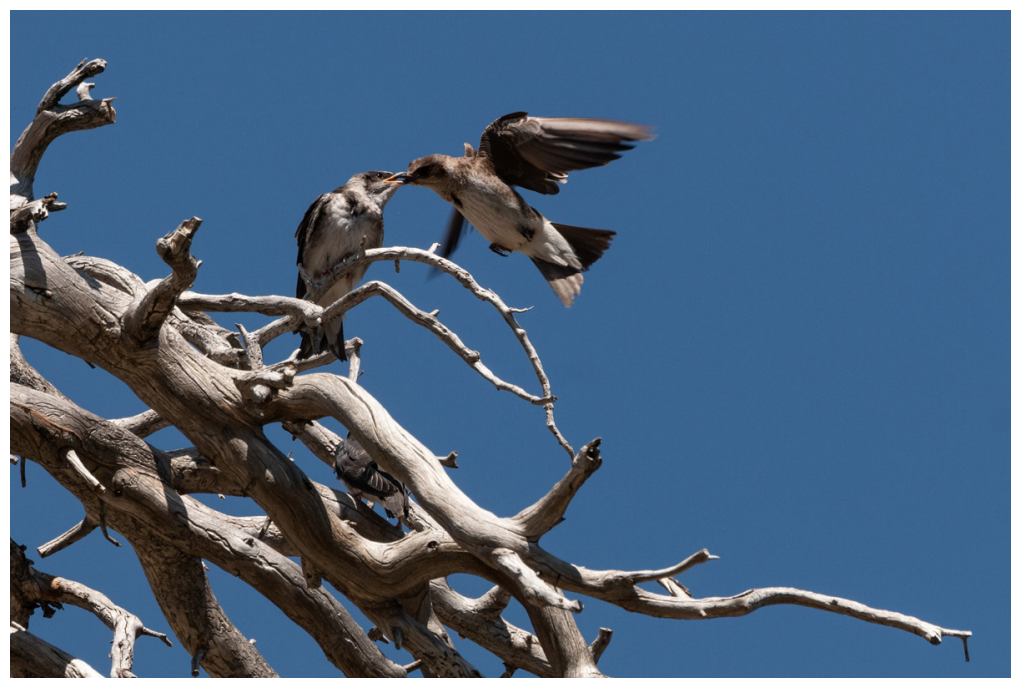

Figure 1. Female Purple Martin (one year old) feeding two fledglings at Lake Cleveland, Cassia Co., Idaho, on 11 August 2019.

Photo by Teresa Meachum

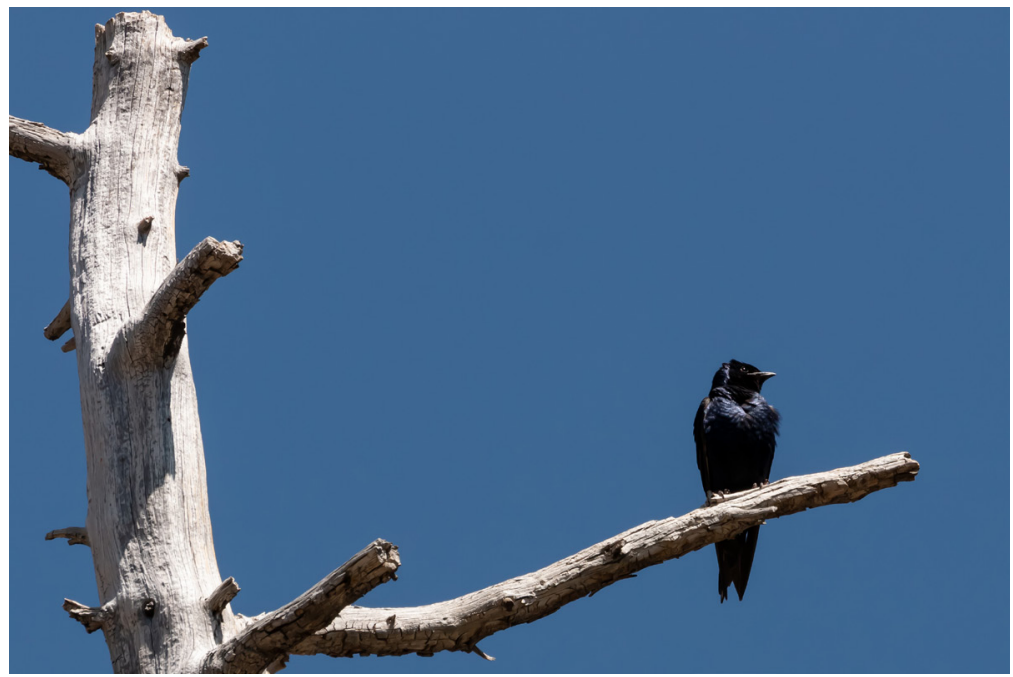

Figure 2. Adult male Purple Martin perched above the nest cavity at Lake Cleveland, Cassia Co., Idaho, on 11 August 2019.

Photo by Teresa Meachum 


\section{NOTES}

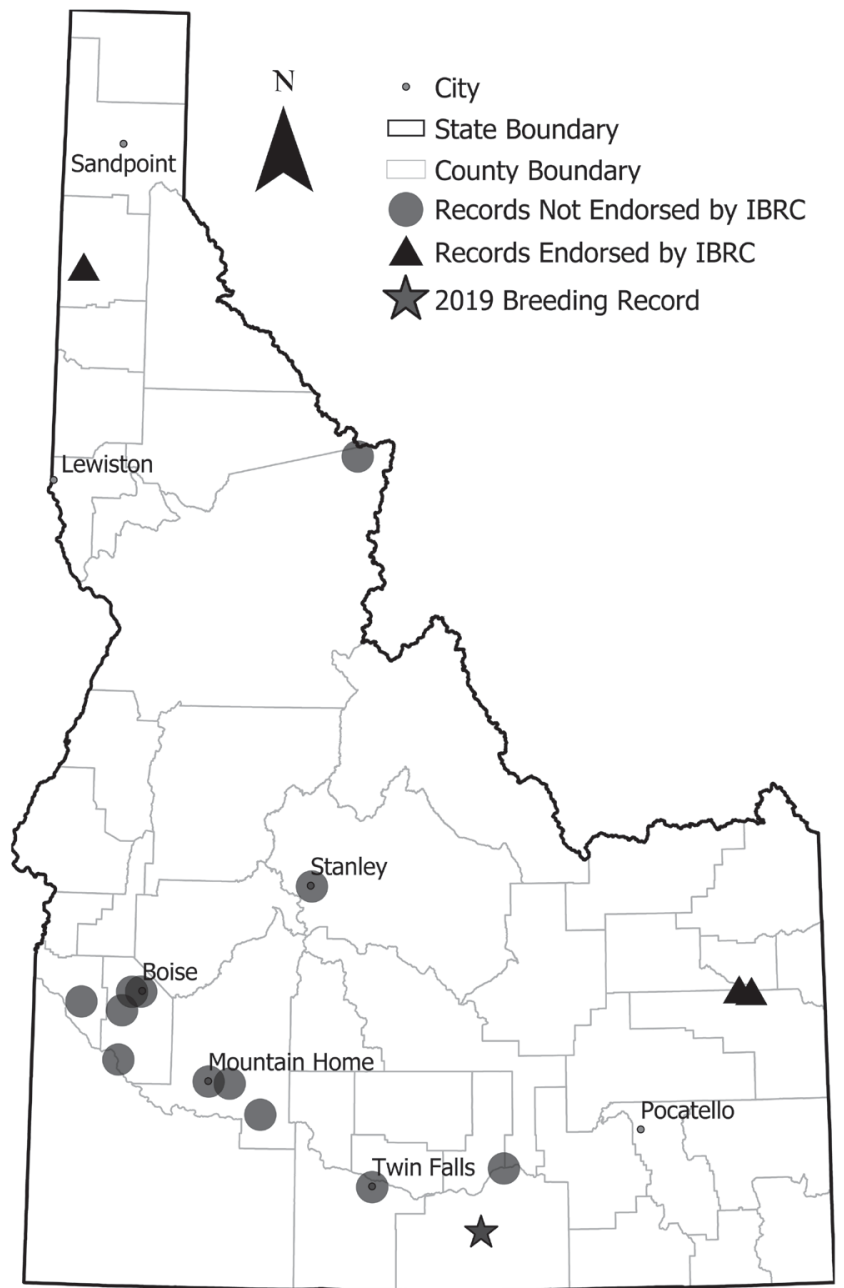

Figure 3. Idaho reports of the Purple Martin.

detailed information about Purple Martin ecology. We thank local birder Teresa Meachum for her photographs.

\section{LITERATURE CITED}

Airola, D. A., and Kopp, D. 2018. Another substantial decline in the Sacramento Purple Martin nesting population in 2018: The role of construction disturbance and future threats. Central Valley Bird Club Bull. 21:75-88.

Airola, D. A., and Williams, B. D. C. 2008. Purple Martin (Progne subis), in California bird species of special concern: A ranked assessment of species, subspecies, and 


\section{NOTES}

distinct populations of birds of immediate conservation concern in California (W. D. Shuford and T. Gardali, eds.), pp. 293-299. Studies of Western Birds 1. W. Field Ornithol., Camarillo, CA, and Calif. Dept. Fish and Game, Sacramento.

Behle, W. H. 1968. A new race of Purple Martin from Utah. Condor 70:166-169; doi.org/10.2307/1365959.

Brown, C. R., and Tarof, S. 2013. Purple Martin (Progne subis), in The Birds of North America Online (A. Poole, ed.), no. 287, version 2.0. Cornell Lab Ornithol., Ithaca, NY; doi.org/10.2173/bna.287.

Cousens, B., Lee, C. J., Darling, L. M., Finlay, C. J., and Gillespie, T. W. 2005. Two decades of Purple Martin stewardship and recovery in British Columbia-successes and challenges. Proceedings of the 2005 Puget Sound Georgia Basin Research Conference, p. 9. Puget Sound Inst., Univ. Wash., Seattle.

Doughty, R. W., and Fergus, R. 2002. The Purple Martin. Univ. of Texas Press, Austin.

Hayward, L. C. 1941. Notes on the nesting habits of some mountain dwelling birds in Utah. Great Basin Nat. 2:3-4.

Hayward, L. C. 1958. Additional notes on the Purple Martin in Utah. Condor 60:406; doi.org/10.1093/condor/60.6.406.

Kostka, S., and McAllister, K. 2005. Purple Martin, Progne subis, in Birds of Washington: Status and Distribution (T. R. Wahl, B. Tweit, and S. G. Mlodinow, eds.), pp. 269-270. Ore. State Univ. Press, Corvallis.

Orr, R. T. 1951. Observations on the birds of northeastern Idaho. Proc. Calif. Acad. Sci. 27:1-16.

Pyle, P. 1997. Identification Guide to North American Birds, part 1: Columbidae to Ploceidae. Slate Creek Press, Bolinas, CA.

Stutchbury, B. J. 1991. Coloniality and breeding biology of Purple Martins (Progne subis hesperia) in saguaro cacti. Condor 93:666-675; doi.org/10.2307/1368198.

Stutchbury, B. J. M., Tarof, S. A., Done, T., Gow, E., Kramer, P. M., Tautin, J., Fox, J. W., and Afanasyev, V. 2009. Tracking long-distance songbird migration by using geolocators. Science 323:896-896; doi.org/10.1126/science.1166664.

Wilbur, S. R. 1976. New seasonal and distributional records of Idaho birds. Murrelet 57:32-34; doi.org/10.2307/3534536. 